\title{
HUMAN RIGHTS IN SOUTH AFRICA: A GENERAL EXPO- SITION WITH AN EMPHASIS ON POLITICAL PRISONERS
}

\author{
Alfred T. MOLEAH
}

South Africa remains the one singular exception to the current world-wide concern with Human Rights. This is not surprising because the whole system that defines and determines South African society is inherently and intrinsically inhuman. Racism is the bedrock of South African society.

This is not to suggest that South Africa is the only country or society in the world that practices racial discrimination. What makes South Africa stand out or even unique, is that in South Africa racial discrimination is not merely socially condoned, but is legally endorsed and required by a carefully constructed legal order premised on racial separation and racial discrimination. Unlike in most societies, the law is not a protection against racial discrimination, but is actually the fount of such discrimination. In South Africa, Parliament is an instrument whereby whites exploit and oppress Africans. Discrimination characterized the South African Parliament from its very inception. The South African Act of 1909, to which Parliament owes its existence, in sections 26 and 44 lays down that every member of Parliament must be "a British subject of European descent," thus excluding the African majority on purely racial grounds. ${ }^{1}$ This racist foundation was built upon and augmented incrementally until devised into a total system, after World War II.

When the present Nationalist Party Government came into power in 1948, it fashioned what was still then a motley of discriminatory laws and practices into a system of white sup-

1 Edgar H. Brookes and J. B. Macaulay, Civil Liberty in South Africa (New York: Oxford University Press, 1958), p. 43. 
remacy, known as Apartheid. In the 1950 's, discriminatory legislation rapidly piled up in the South A.frican statute books. Mere discriminatory practices of the past were now given a legislative seal, and areas hitherto unaffected by any conscious racial discrimination now received official attention. In short, a system of total racial discrimination was fashioned to insure white supremacy and black subordination in all spheres of life. South Africa became a thoroughly racist society. It is important to note that while South Africa embarked with great zeal and singleness of purpose to create a racist society, the rest of the world had began, slowly, to move away from racial discrimination. In many countries, legal processes were invoked on both the national and international plane to prohibit racial discrimination. It was during this period that the great blow against racial discrimination was struck in the United States of America when the Supreme Court rendered a decision in Brown v. Board of Education of Topeka (1954), which nullified the "separate but equal doctrine" established by Plessy v. Ferguson (1896). As the United. States Supreme Court pronounced racial separation as inherently premised on a superior-inferior valuation of human beings, South Africa had just gone in the opposite direction by passing the Bantu Education Act of 1953 which mandated separate and unequal education for Africans. Even more importantly, the period of hectic official action to insure racial discrimination in South Africa ironically coincides with efforts by the international community to move away from racial discrimination as a necessary pre-condition for recognizing and respecting Human Rights, viz. the Universal Declaration of Human Rights (1948); the European Convention for the Protection of Human Rights and Fundamental Freedoms (1950); the International Convention on the Elimination of All Forms of Racial Discrimination (1965) and the International Covenant on Civil and Political Rights (1966).

The South African Government remained unrepentant, in fact, self-righteous in the face of international protest and condemnation. Its only notable concession was to engage in terminological and nomenclatural mutations to assuage international disapproval by cynical deception. Apartheid, a term and concept which had rightfully evoked international opprobrium was slowly phased out and replaced with such innocuous 
terms as "differentiation without inferiority," "constructive differentiation," "policy of multi-nationalism," "separate frecdoms," "harmonious multi-community development" and has now mainly settled on "separate development" and "plural democracy." 2

This deception has now assumed the status of policy. The "new polisy" was exposed to the world in 1974 by Mr. R. F. Botha, then South Africa's Ambassador to the United Nations, (now Foreign Minister) in the course of the Security Council debate on South Africa's continued membership in the United Nations. He stated:

"Our policy is not based on any concept of superiority or inferiority, but on the historical fact that different peoples differ in their loyalties, cultures, outlooks and modes of life and that they wish to retain them... We do have discriminatory practices and we do have discriminatory laws... Those laws and practices are a part of the historical evolution of our country... But I want to state here today very clearly and categorically: my Government does not condone discrimination purely on grounds of race or color.,"3

South Africa has increasingly resorted to another insidious distinction between "Petty Apartheid" and "Grand Apartheid." "Petty Apartheid" being adjudged annoying and unnecessary will be done away with viz., racial segregated entrances, parkbenches, etc., but "Grand Apartheid," as historically derived and necessitated, will stay viz., the "pass system," denial of the vote to Africans, separate institutions, etc. Instead of a change, South Africa offers endless machinations and continues to stand in contemptuous contravention of all international accords and conventions on Human Rights. In South Africa, a person's political, civil, economic and social rights are determined by the racc or ethnic group to which he / she belongs and to that effect, an elaborate legislative scheme has been established to identify each person racially.

2 John Dugard, Human Rights and the South African Legal Order (Princeton, N.J.: Princeton University Press, 1978), pp. 53-4.

3 Quoted in Ibid., p. 54. 
South Africa had an estimated population of 26.1 million (1976). The racial breakdown is as follows:

\begin{tabular}{|c|c|c|}
\hline African & 18.6 million & $71 \%$ \\
\hline White & 4.3 million & $16 \%$ \\
\hline Coloured $*$ & 2.4 million & $9 \%$ \\
\hline Indian / Asian & .7 million & $3 \%$ \\
\hline
\end{tabular}

The projected population figures for the year 2000 are:

$\begin{array}{lr}\text { African } & 34.7 \text { million } \\ \text { White } & 6.6 \text { million } \\ \text { Coloured } & 4.7 \text { million } \\ \text { Asian } & 1.3 \text { million }^{5}\end{array}$

The Workforce (1975) was:

$\begin{array}{lrc}\text { African } & 7.0 \text { million } & 71 \% \\ \text { White } & 1.8 \text { million } & 16 \% \\ \text { Coloured } & .8 \text { million } & 8 \% \\ \text { Asian } & .2 \text { million } & 2 \%\end{array}$

Incom: Distribution (1975) was:

$\begin{array}{lr}\text { African } & 23 \% \\ \text { White } & 67 \% \\ \text { Coloured } & 7 \% \\ \text { Indian } & 3 \%\end{array}$

Employment and Wages $(1975 / 76)$ were:

\begin{tabular}{|l|c|c|c|c|}
\hline & \multicolumn{2}{|c|}{ Mining 1975} & \multicolumn{2}{c|}{ Manufacturing 1976} \\
\cline { 2 - 3 } & Employment & Wages /mo. & Employment & Wages /mo. \\
\cline { 2 - 3 } African & 591,730 & $\$ 90.85$ & 757,700 & $\$ 134.55$ \\
White & 91,632 & $\$ 678.50$ & 300,200 & $\$ 632.50^{\text {. }}$ \\
\cline { 2 - 3 }
\end{tabular}

Per Capita Income, 1975 was: \$ 14.38 African $\$ 209.30$ White $^{9}$

\# Mixture of black and white.

4 Stated of South Africa Yearbook 1976-77.

5 A Survey of Race Relations in South Africa 1976 (Johannesburg, S.A.: South African Institute of Race Relations, 1977), p. 32.

6 Financial Mail, 4/15/77.

7 Finnancial Mail, 5/6/77.

8 Financial Mail, 5/30/75.

$9 \times$ Ray, March/April 76. 
Average Monthly Household Income, (1975) was:

$\begin{array}{ll}\text { African } & \$ 83.95 \\ \text { White } & \$ 711.85 \\ \text { Coloured } & \$ 243.80 \\ \text { Indian } & \$ 366.85^{10}\end{array}$

Black unemployment now stands at about 2 million and is growing by about 10,000 a month.11

Average Expenditure per pupil for Primary and Secondary Education, 1974-1975 was:

$\begin{array}{ll}\text { Whites } & \text { R*605.00 } \\ \text { Africans } & \text { R } 39.53 \\ \text { Coloureds } & \text { R } 125.53 \\ \text { Indians } & \text { R } 170.94^{12}\end{array}$

Teacher: Pupil Ratio (1975) was:

$\begin{array}{ll}\text { White } & 1: 20.1 \\ \text { African } & 1: 54.1 \\ \text { Coloured } & 1: 30.6 \\ \text { Asian } & 1: 26.9^{13}\end{array}$

Number of Students in Primary and Secondary Schools

$\begin{array}{lc}\text { White } & 903.062 \\ \text { African } & 3.698 .921^{14}\end{array}$

Number of Schcols for each race group

$\begin{array}{lc}\text { White } & 2.493 \\ \text { African } & 12.378^{15}\end{array}$

Compulsory education for Africans is to be provided by 1980 , but this does not seem likely as the budget has bzen cut by $9 \%$ when an increase of $20 \%$ was determined as the minimum condition to make this possible. ${ }^{16}$ This reduction of the budget for

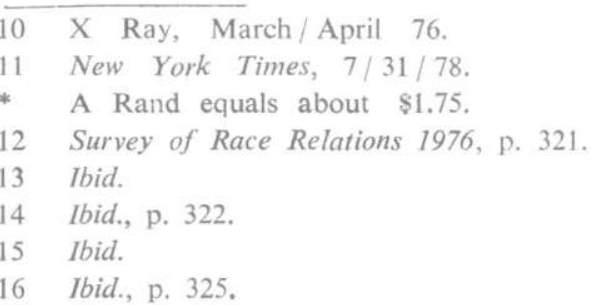


African education has further serious implications, in that it will now not be possible to build the needed schools. Soweto alone has a backlog of about 800 classrooms or 70 schools. ${ }^{17}$

Between June 1974 and May 1975, the following racial group students received degrees and diplomas:

\begin{tabular}{|l|c|c|c|c|}
\hline Whites & $\begin{array}{c}\text { Post-Graduate } \\
\text { Degrees }\end{array}$ & $\begin{array}{c}\text { Bachelors } \\
\text { Degrees }\end{array}$ & $\begin{array}{c}\text { Post-Graduate } \\
\text { Diplomas }\end{array}$ & $\begin{array}{c}\text { Non-Graduate } \\
\text { Diplomas }\end{array}$ \\
\cline { 2 - 3 } Coloureds & 3.510 & 9.038 & 1.785 & 1.134 \\
Asians & 20 & 196 & 59 & 12 \\
Africans & 64 & 422 & 39 & 58 \\
\hline
\end{tabular}

From the above statistics, the picture of non-white, Africans in particular, disadvantages and denials of human rights can be gleaned. Whites, by reason of their color, are able to derive inordinate advantage of all the benefits the society has to offer. Africans, conversely, derive the least benefit because the society relagates them the lowest status. The sole determinant is the color of one's skin. Because of this, South Africa, with absurd meticulosity, classifies each person into the pigeon-hole of white, coloured, Asian and black in accordance with the Population Registration Act of 1950. This Act, undaunted by the failure of the geneticist and the anthropologist to compile a complete and perfect grouping of people along racial lines, has constructed a racial classification scheme based on the criteria of descent appearance and general acceptance. ${ }^{19}$ In spite of this serious difficulty, this Act remains the cornerstone of the whole system of Apartheid.

Africans are not only relegated to an inferior social status, but have constant and commonplace reminders of that inferior status. The South African landscape abounds in these constant reminders - there are signs everywhere barring Africans from public amenities. At issue here is not the question of separation, as unacceptable as that may be, but separation to ensure inequality. South Africa's philosophy is "separate and unequal." 20 The

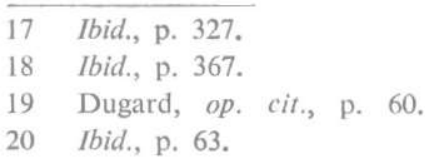


much vaunted raforms of 1973 onwards which are supposed to eliminate "petty apartheid" are, at best, cosmetic and, at worst, a plain farce. When, between 1973 and 1974, several city councils decided to make facilities under their control available to all races, they had to abide by the limitations of the Group Areas Act of 1966 which prohibits the opening of restaurants, swimming pools and theatres to all races without the consent of the central Government. Such tepid reforms also provoked a warning from the, then, Prime Minister, Mr. B. J. Vorster that: "The Government will constantly keep an eye on the position and, should city councils' intended steps cause friction or disturb the peace, the Government will not hesitate to "intervene and to rectify the situation." This warning concretized in the form of a Bill introduced in 1976 and reintroduced in 1977, the Reservation of Public Amenities Amendment Bill to enable the Government to maintain separate facilities for different races. The introduction of this measure gives the lie to the Government's claim of doing away with "petty apartheid." 21

South African statute books are replete with racist and discriminatory legislation all aimed at denying non-whites, especially the African majority, of their human rights. We can, however, not go into all of them for our present purposes. We shall irstead simply mention and comment on a few that go to the heart of the issue of the denial of human rights.

As already mentioned, the Population Registration Act of 1950 is the basic means of racial discrimination in South Africa. This Act is a denial of the common humanity of all persons and makes race the main consideration. This Act violates directly Article 1 of the Universal Declaration of Human Rights which states: "All human beings are born free and equal in dignity and rights. They are endowed with reason and conscience and should act towards another in a spirit of brotherhood." Other Acts compound this denial of the brotherhood of mankind and uphold and encourage its very opposite. In the process of so doing, they also violate other provisions of the Universal Declaration of Human Rights, in this case Article 16(1). "Men and women of full age, without any limitation due to race, nationality or reli-

$21 \quad$ Ibid., p. 67. 
gion, have the right to marry and found a fa nily. They are entitled to equal rights as to marriage, during marriage and at its dissolution." This violation and contravention are represented by the Immorality Act of 1927, which prohibited any carnal intercourse outside marriage between Europeans (whites) and Africans. In 1950, an Amendment to this Act extended this prohibition to all classes of non-Europeans, namely, Africans, Asians and Coloureds.22 When the Nationalist Party Government took power in 1948, one of its first Acts, to systentatize and give legal sanction to racial discrimination, was the passage of the Prohibition of Mixed Marriages Act of 1949, which forbids marriages between a European and a non-Europzan and provides that any union entered into in contravention of this law "shall be void and of no effect." A marriage officer who performs a marriage ceremony in contravention of this law commits a criminal offense. The purported purpose of these two laws was to ensure sexual morality, but the real purpose was to foster racial discrimination by maintaining the purity of the white race, and to maintain that purity by preventing Coloureds from "infiltration." While the world was retreating from such racist postures, South Africa extended the scope of the Prohibition of Mixed Marriages Act by applying its provisions to marriages entered into outside South Africa. This law has more of an effect in affirming and advancing a racist ideology rather than solving a practical problem. Before 1949, mixed marriages were rare in South Africa, averaging about one-hundred per year between 1943 and 1946 and even less before that. ${ }^{23}$ Another of its rationalizations - that the Act was needed to protect white women from the lust of black men - proved equally groundless because in the period July 1972 to June 1973, 161 white men and 135 black women were convicted under its provisions as opposed to only 5 white women and 3 black men during the same period. ${ }^{24}$

Africans in South Africa do not have any of the rights commonly associated with citizenship, simply because the current political system and its laws do not recognize them as citizens.

22 South Africa and the Rule of Law (Geneva: International Commission of Jurists, 1960), p. 56.

23 Ibid., p. 57.

24 Dugard, op. cit., p. 71. 
Africans are simply seen as labor units whose presence is only justifiable by the labor requirements of whites. Laws exist to enforce this absurd contention. The Bantu* Land Act of 1913 and the Bantu Trust and Land Act of 1936 together set aside some thirteen per cent of the total area of South Africa for the exclusive cccupation of Africans. The 1913 Act demarcated certain areas, known as "reserves"** for Africans and forbade the transfer to, or lease of land by, other races within these reserves. At the same time, Africans were prohibited from acquiring land elsewhere..$^{25}$ As of late, these are also areas within which Africans will be able to exercise sovereignty and reclaim their rights of citizenship. Conversely, eighty - seven per cent of South Africa (with the best land, mineral resources and all major urban and industrial centers) is designated "white South Africa." So, officially all Africans in "white South Africa" are temporary sojourners, there only to sell their labor in accordance with its needs and requirements. There were already Africans in "white South Africa" (about $50 \%$ of the African population) whose presence could not be simply washed away. The Group Areas Act with its latest amendment of 1966 was brought in to solve this problem - its cumulative effect is to deny Africans all citizenship rights in "white South Africa" and to carefully regulate their presence on a racially segregated basis. Africans are, therefore, migrant laborers in eighty - seven per cent of their country with no rights, in fact, no basis to have rights since they are officially foreigners. It is from this anomaly that all their disadvantages and disabilities derive.

Africans are accordingly restricted from being in the white areas, they have to account for their presence there and are faced with the constant threat of arbitrary expulsion while there. The Bantu (Urban Areas) Consolidation Act of 1945, as amended, controls the influx of Africans into urban areas and controls their conduct while there. Section 10 of this Act makes it an offense punishable by a fine, imprisonment and "repatriation"

\footnotetext{
* Until recently this was the designation applied to all Africans because whites had already arrogated to themselves the term Afrikaner - the Dutch term for African (descendent of the Dutch settlers).

** These are supposed to be areas that Africans occupied before whites came, and, therefore, the only areas that they could rightfully claim. 25 Ibid., pp.78-9.
} 
for an African to remain for longer than seventy-two hours in an urban area unless he is able to show that (a) he has resided in such an area continuously since birth; or (b) he has worked continuously in such an area for the same employer for ten years; or (c) he has lawfully resided continuously in such area for at least fifteen years; or (d) the African is the wife, unmarried daughter, or minor son of a male falling under (a), (b) or (c); or (e) permission has been granted for him to remain by a labor bureau. Even when an African qualifies under these conditions to be lawfully in an urban area, he still cannot move freely within that area, he can be restricted to and from certain areas and is subject to night curfew. ${ }^{26}$ Urban residence for Africans is not a right but a privilege, and as such, it can always be withdrawn for, among others, any offense carrying a minimum penalty of six months in jail or a fine equivalent to $\$ 115.00$. It can also be cancelled by the courts if they find an otherwise qualified man to be "idle and undesirable" - a phrase that can cover prolonged unemployment through no fault of his own.27

The ultimate control of Africans in the urban areas of socalled "white South Africa" is effectuated through the "pass system." A pass is a document legally required of all Africans over the age of sixteen, indicating, among others, permission to be in that particular area of "white South Africa," place of employment or permission to seek employment, tax-payment status and personal details. All Africans are to produce their pass on demand, and not to do so, for any reason, constitutes an offense punishable by a fine or imprisonment. The pass system is old in South African history, but when the present Nationalist Government embarked on its policy of "modernizing" racial discrimination, the old pass system was replaced in 1952 by a statute bearing the misleading title of the Bantu (Abolition of Passes and Co-ordination of Documents) Act which, instead of abolishing passes as its title purported, streamlined them and made them even more onerous to Africans and extended them to African women for the first time. As the history of African political struggle so clearly indicates, the pass system is the one item in South Africa's racist-laws edifice that Africans

$26 \quad$ Ibid., p. 74.

27 New York Times, 5/24/78. 
perceive as the very embodiment of their dispossession and denial of their humanity.

Africans who have their passes in order are still not secure and protected in the urban areas. Section 29 of th 3 Bantu (Urban Areas) Consolidation Act permits a police officer to arrest without warrant any African whom he "has reason to believe" is "an idle or undesirable person" and to bring him before a Bantu Affairs commissioner, who "shall require such Bantu to give a good and satisfactory account of himself." After an administrative inquiry, the commissioner may declare the African to be "idle" if he is habitually unemployed, or "undesirable" if he has previously been convicted of certain offenses (which include political offenses), and order him to be sent to his homeland, to a rehabilitation centre, or to a farm colony for a period not exceeding two years, or, with his consent, to an approved employer on contract for a specified period. In 1956, a new section was added onto Section 29, which empowers a Bantu affairs board to order the removal of an African from an urban area where it is of the opinion that his presence is "detrimental to the maintenance of peace and order in any such area." The purpose of this provision is to confer upon local authorities arbitrary powers to rid themselves of political "agitators." 28 More than the actual oppression as spelled out in the laws that govern them, Africans suffer from an acute sense of insecurity never knowing how to conform to even the most oppressive law. In spite of the great number of laws that are geared towards African suppression, African rule and control are basically arbitrary. This is because these laws largely depend on bureaucratic whims for their implementation and since Africans, in most cases, have no legal recourse; the whim becomes final as law. This is ample testimony to Arendt's contention that bureaucratic rule is rule without accountability since it is rule by Nobody and that "rule by Nobody is clearly the most tyrannical of all, since there is no one left who could even be asked to answer for what is being done." 29

South Africa represents, for the African majority, the most complete case of a denudation of human rights. White South

28 Dugard, op. cit., p. 77.

29 Hannah Arendt, "Reflections on Violence," Journal of International Affairs, (Vol. XXIII, No. 1, 1969), p. 13. 
African politics are simply the politics of African dispossession and suppression - denial of the most basic human rights. For the African in South Africa there are no avenues, not only to change the condition, but just to ameliorate it. The Bantu Education Act of 1953 aimed at lowering the already low standard of African education by tight government control and a new emphasis on manual labor. The 1959 Extension of University Education Act (another misnomer in the now typically South African fashion) barred Africans from white universities and established inferior tribal "universities." As to the aim of these education laws, the then Minister of Bantu Education stated in Parliament June 1959: "Our aim is to keep the Bantu child a Bantu child. The Bantu child must be so educated that they do not want to become imitators (of the whites) but that they will want to remain especially Bantu." With these remarks, he had merely echoed a similar position by the then Minister of Native Affairs and later Prime Minister, Dr. H. F. Verwoerd who stated in 1954:

"The BANTU must be guided to serve his own community in all respects. There is no place for him in the European country above the level of certain forms of labour... It is of no avail for him to receive a training which has as its aim absorption in the European community, where he cannot be absorbed." ${ }^{\prime 30}$

Africans are equally barred from advancement through skilled and lucrative employment. Just about all skilled (and well-paid) jobs are reserved for whites. White unions have always made sure that no Africans are admitted as apprentices. There is also an unwritten law, scrupulously observed nevertheless, that no white employee shall be subordinate to a black. The African work-force has been emasculated by an almost total absence of union power to bargain for and improve their lot. ${ }^{31}$

\section{Imprisoned Society}

It is not an exaggeration to observe that for Africans, South Africa is a prison. African lives are shackled from the cradle

30 Quoted in The Times (London), 5/31/60.

31 Dugard, op. cit., p. 86. 
to the grave. For the racist white minority to maintain its privileged position, African subdugation must be constant and complete. Lest the oppressed African majority become a real threat to the privileged white minority position, it is essential that they be constantly tyrannized and brow-beaten. As already seen, white privilege is maintained through a plethora of draconian laws, and white support for the government is ensured through insistent reminders of "die swart gevaar"* - a slogan that won the Nationalist Party power in 1948 and every election thereafter.

As already stated, the Nationalist Party Government that has ruled South Africa, since 1948 has tried to resolve South Africa's fundamental dilemma, retaining African labor to ensure white comfort and privilege and barring Africans from all political, economic and social power positions, lest they challenge their inferior status - by an ingenuous contrivance that declares South Africa a multi-national and not multi-racial society; lumping all whites into one nation and blacks into seven different nations, and by this alchemy make the white "nation" the third largest group in the country; dividing up South Africa whereby the white "nation" retains $87 \%$ of the country and blacks in "white South Africa" become temporary sojourners there only to sell their labor with no citizenship rights. This demented scheme has tragic consequences for the African majority. This was succinctly put forth by the then Minister of Bantu Administration in 1970, when he stated: "As far as I am concerned the ideal condition would be if we could succeed in due course in having all Bantu present in the white areas on a basis of migratory labour only." 32 In pursuit of this "nightmare", nearly one million Africans were removed by 1969 and millions of "superfluous Bantu" are and will suffer the same fate. For the millions of Africans who are needed to sustain the economy and white privilege it serves, "bachelor hostels" are built, and they all simply become "statutory bachelors." This determination applies to men and to women who for purposes of this scheme are simply adjudged single.

* The black danger.

32 Quoted in Allen Cook. South Africa: the Imprisoned Society (London: International Defence and Aid Fund, 1974), p. 6. 
Cook correctly observes that:

"The appalling fact of apartheid is that a society has been created whereby, for the blacks, the conditions of ordinary life (italics in original) are comparable to those of imprisonment, in terms of conditions normally held to constitute imprisonment: forcible separation from families, controlled living in security institutions behind barbed wire, and supervision by persons with wide powers to command and punish." 33

These "bachelor tostels" are hardly distinguishable from prisons. They are overcrowded with minimal amenities; the different sexes are not allowed in the rooms; no children are allowed; there are punishment cells where those who infringe, even the most trivial, hostel regulations are confined; they are surrounded by barbed wire fences and the comings and goings of the "inmates" are strictly regulated and they are generally infested with vermin and all kinds of diseases. ${ }^{34}$

For the "superfluous Bantu" - those who lose their jobs or who are "endorsed out" for one reason or another, including being "undesirable" (that is, having committed a political offense) including their "superfluous appendages" (children, wives, old people), there are the "resettlement villages" in the "homelands." These "resettlement villages" are desolate. There is usually no preparation to receive the people; no facilities such as roads, stores, water or even jobs. A report from such a resettlement village, Sada, near Queenstown in 1968, said that public health was endangered through bodies being kept in houses until they could be disposed of; a Queenstown health official said Sada was "rotten with tubərculosis" withcut any proper health services and no facilities for pauper burials. ${ }^{35}$ Another such place is Nondweni Township called "Tin Town" by the "residents" in the Kwa-Zulu area. It too, like all others, has no job opportunities, no social amenities or even stores; the children have to walk seven miles to the nearest school and the "residents" have to draw water from a nearby stream that is green

33 Ibid.

34 Ibid., p. 7.

35 Ibid., p. 8. 
with algae. ${ }^{36}$ An indication of the Government's own view of the "resettlement villages" is seen in the fact that African political prisoners are almost invariably banished to them on their release from prison. Therefore, apart from providing dumping grounds for human "superfluous appendages," the villages also function as cheap places of imprisonment. ${ }^{37}$

Given the repressive conditions of South African society, prisons are central to it. There are over 240 prisons as compared to 70 in the United Kingdom, with a population more than twice that of South Africa. Further comparative figures with other countries bring out the tragic dimensions of the South African situation.

\begin{tabular}{|l|r|c|c|}
\hline \multicolumn{1}{|c|}{$\begin{array}{c}\text { 1970-71 } \\
\text { Country }\end{array}$} & $\begin{array}{c}\text { Total } \\
\text { Population }\end{array}$ & $\begin{array}{c}\text { Actual Numbers } \\
\text { in Prison }\end{array}$ & $\begin{array}{c}\text { Numbers in Prison } \\
\text { (per 10,000 of } \\
\text { Population) }\end{array}$ \\
\hline Norway & 3.9 million & 1,432 & 3.7 \\
Britain & 55.5 million & 40,178 & 7.2 \\
West Germany & 61.2 million & 51,175 & 8.4 \\
South Africa & 21.4 million & 474,064 & $221.5^{38}$ \\
\hline
\end{tabular}
Africans.

Of this total South African prison population, 403,159 were

South Africa's daily average prison population was 91,108 in 1971 , rose to 95,015 in 1973 , and is now more than 100,000 .

One out of every four African adults is imprisoned every year. Of these, "pass laws" account for more than $42 \%$ of the short term imprisonment.

According to a report of the Commissioner of Police of 1970-71, 615,075 people were prosecuted under the pass laws. In addition, 178,085 people were prosecuted for trespassing, i.e., curfew violations. There were also 105,576 prosecutions for infringement of the "Bantu tax laws."

The daily average of sentenced and unsentenced prisoners in 1974-75 was:

36 Christian Science Monitor, 10/26/79.

37 Allen Cook, op. cit., p. 8 .

38 Ibid., p. 9. 


\begin{tabular}{|l|r|r|r|}
\hline & \multicolumn{1}{|c|}{ Male } & Female & \multicolumn{1}{|c|}{ Totals } \\
\cline { 2 - 3 } White & 3,932 & 90 & 4,022 \\
African & 69,498 & 5,150 & 74,648 \\
Asian & 528 & 15 & 544 \\
Coloured & 17,913 & 921 & $\frac{18,834}{}$ \\
\hline & 91,872 & $\frac{6,176}{98,048^{39}}$ & \\
\hline
\end{tabular}

Thus, for Africans in South Africa, the everpresent imminence of imprisonment is a universal experience. ${ }^{40} \mathrm{Ar}$ rest and imprisonment are such daily features of African existence in South Africa that anytime a person is missed for a few days, the common assumption among friends and relatives is that he/she has been picked up by the police. The central importance of African suppression and repression is reflected by the unstinting budget allocation of 1976-7:

\begin{tabular}{|c|c|}
\hline $\begin{array}{l}\text { Security Service Special Account } \\
\text { Defence } \\
\text { Police } \\
\text { Prisons }\end{array}$ & $\begin{array}{r}11,830,000 \\
1,350,000,000 \\
176,900,000 \\
70,900,000\end{array}$ \\
\hline Totals & $1,609,630,000$ \\
\hline
\end{tabular}

This represents $19.96 \%$ of the budget.

Africans found in contravention of the numerous laws that control and regulate their lives in the urban centers can now also be referred to Aid Centers instead of jail. In typical South African fashion such consideration remained at best a farce. According to the Minister of Bantu Administration and Development, the number of Africans referred to Aid Centers during 1975 were as follows:

\section{1,537 referred to Aid Centers}

Of that number 121,314 were not subsequently prosecuted 21,636 were assisted $*$ to find employment

61,242 were returned** to homelands

31,775 reported voluntarily

Of those who reported voluntarily 5,718 were returned to homelands.

39 Survey of Race Relations 1976, p. 93.

40 Allen Cook, op. cit., p. 10.

* Assistance usually means the choice between an undesirable job and imp. risonment or "endorsement out."

** Many of those returned to homelands had never been there before and in many cases had no roots or family in such place. 
South Africa has more than political reasons for maintaining such a high prison population. Prisoners also serve as a cheap labor pool, especially for farmers who are always hard-pressed for labor, because of the poor wages they pay (even by South African standards) and the abominable working and living conditions. In 1957-8, 199,312 prisoners were being hired out to farmers annually at a wage of $9 \mathrm{~d}$ per day (less than 20 American cents). The work and living conditions are so horrid for these prisoners that the Government, instead of responding with reforms to press exposures of these conditions, simply passed a law, the 1959 Prison Act, which made such farms statutory prisons and prevented the publication of any information concerning them. From time to time, facts came to light in the courts about conditions in farm goals. In a trial of a prisoner who had escaped from Geluk prison in the Bethel area in 1973, a director of Prisoners' Aid in Johannesburg told the court how one farmer made the prisoners work from 3:30 a.m. until 11:00 p.m. The farmer confirmed this to her personally in the presence of a policeman. The prisoners' few hours of sleep were spent on mealie (maize) bags on a cement floor. ${ }^{41}$ Industry and government departments also take advantage of this source of cheap and tractable labor, so do plenty of private individual whites. This system continues albeit in greater secrecy because of the 1959 Prison Act. The Minister of Prisons stated in Parliament that during 1975 , a daily average of 5,575 prisoners worked for government departments, provincial administrations and subsidized institutions, while an average of 16,662 worked for local authorities and private persons. During the same year, 87,543 prisoners were released on parole and placed in employment with various employers, including farmers. ${ }^{42}$ African mental patients - who abound in inordinate numbers because of the inhuman conditions racism creates - are another source of cheap labor. In $1977,8,000$ or more such mental patients were "farmed out" by the South African Government as cheap and easily exploitable labor to a private profit-making corporation. ${ }^{43}$

\footnotetext{
41 Ibid., p. 12.

42 Survey of Race Relations 1976, p. 93.

43 Political Imprisonment in South Africa 1978 (London: Amnesty International, 1978), p. 105.
} 
The police in South Africa, as guardians of the racist order, have become law unto themselves. While in other parts of the world police abuses and police brutality are becoming issues of increased concern, in South Africa such practices are so accepted that they hardly raise a murmur from the responsible authorities. The Minister of Police gave the following figures of civilians shot by policemen in the execution of their duties during 1975 (1974 figures in brackets):

\begin{tabular}{|l|c|c|c|c|}
\hline & \multicolumn{2}{|c|}{ Killed } & \multicolumn{2}{c|}{ Wounded } \\
\cline { 2 - 3 } & Adults & Juveniles & Adults & Juveniles \\
\cline { 2 - 3 } White & $1(2)$ & $-(-)$ & $3(2)$ & $-(-)$ \\
Coloured & $21(4)$ & $4(-)$ & $70(25)$ & $9(1)$ \\
Asian & $1(-)$ & $1(-)$ & $1(-)$ & $-(-)$ \\
African & $103(45)$ & $3(-)$ & $281(119)$ & $18(12)$ \\
\hline
\end{tabular}

Figures for 1976-7 should be much higher because of the uprisings which started in Soweto (June 1976), and have claimed more than 700 African lives (mostly children between the ages of 7 and 16).

Of these, casualties resulting from attempts to escape arrest* were:

\begin{tabular}{|l|c|c|c|c|}
\hline White & $-(2)$ & $-(-)$ & $3(2)$ & $-(-)$ \\
Coloured & $16(2)$ & $2(-)$ & $67(23)$ & $7(1)$ \\
Asian & $1(-)$ & $1(-)$ & $1(-)$ & $-(-)$ \\
African & $81(36)$ & $1(1)$ & $216(105)$ & $11(10)^{44}$ \\
\hline
\end{tabular}

Africans and other non-whites in South Africa do not only suffer from police "executions", but also from an unprecedented number of judicial "murders" (executions). Hangings in South Africa account for about $90 \%$ of all executions in the Western world. Over the last decade, there have been at least 700 legal executions, including 132 last year. $80 \%$ of those executed. were Africans, the rest Coloureds and very few whites. ${ }^{45}$ This is another instance of South Africa's open defiance of the increasingly humanitarian or humane trends in our present world.

\footnotetext{
* It is common in South Africa for policemen to order Africans to run and then shoot them down.

44 Survey of Race Relations 1976, p. 94.

45 New York Times, 11/19/79.
} 
Whereas the trend throughout the world has been to reduce the number of capital offenses, South Africa has, in fact, increased them. Until 1958, there were three capital crimes - murder, treason and rape. Eight more have since been created: robbery and house-braaking with aggravating circumstances (1958), sabotage (1962), receiving training that could further the objects of communism or advocating: abroad, economic or social change in South Africa by violent means through the aid of a foreign government or institution where the accused is a resident or former resident of South Africa (1963), kidnapping and child-stealing (1965) and participation in terroristic activities (1967). During the 1960 's, South Africa accounted for $47 \%$ of the world's executions. From the time of Union in 1910 until the end of $1975,2,740$ persons have been executed. Of these 2,740 persons less than 100 were white; no white has yet been hanged for the rape of a black, and only six whites have been hanged for the murder of blacks. From 1947 tc 1969, 121 blacks were sentenced to death for the rape of whites, while only 3 whites were sentenced to this penalty for rape (of whites) during the same period. For this same period, 288 whites were corvicted of rape upon blacks and 844 blacks were convicted of rape upon whites. The 288 convictions of whites produced no death sentences, but the 844 convictions of blacks produced 121 death sentences for rape. $* 46$

\section{Political Prisoners}

The South African Government argues that there are next to no political prisoners in South Africa. This contention is not as outrageous as it seems if placed within the context of South African realities. In South Africa, every and any aspect of an African's existence and activity is seen as political. The very African is seen, not as a human being, but as a political equation, e.g. the African birth rate, unemployment rate, crime rate, death rate are all seen within a political context. Anything African

* Because on the Immorality Act and general racist climate, most white women scream rape upon discovery or even the possibility of discovery. Most black women do not report sexual assaults by white men. Even when they do, whites are always given more credibility.

46 Dugard, op.cit., pp. 125-127. 
immediately assumes a political meaning. South Africa is easily the most politicized country in the world. In South Africa, as far as Africans are concerned, political activity is criminal and criminal astivity is political. Stated differently, Cook rightly observes that:

"The system of apartheid is monolithic. Labour laws, racial laws, finance and economics, education, spcrt and entertainment and 'security' are all inextricably interrelated; and there is a tendency to view any kind of opposition to, or breach of, any kind of law or accepted practice as a 'security' (that is, a political) matter. Security policemen interrogate persons suspected of 'falsifying their race'; persons suspected of common-law crimes such as murder and forgery are detained without trial under security laws; people voicing disquiet about the activities of the Security Police are reprimanded by the Government for their 'allegations against South Africa."',47

As should be expected, South Africa has many laws aimed a.t curbing or nullifying any political activity on the part of blacks. Of these, the most important and most notorious are: The "90day detention law" (section 17 of the General Law Amendment Act: 37 of 1963). This empowered a senior police officer to arrest without warrant and detain any person whom he suspected upon reasonable grounds of having committed or having information about the commission of the crime of sabotage or offences under the Suppression of Communism Act of the Unlawful Organizations Act. A detainee was held for the purpose of interrogation until he had, in the opinion of the Commissioner of the South African Police, replied satisfactorily to all questions or for "ninety days on any particular occasion." 48 This ninety day detention period was renewable. This Act was withdrawn in 1965 and replaced with a 180-day detention law. In 1976, the 180-day detention provision was transferred from the Criminal Procedure Act to the Internal Security Act in respect of political crimes. This 180-day law has been superceded by the Terrorism Act of 1967 which permits indefinite detention without trial

47 Allen Cook, op. cit., p. 13.

48 Dugard, op. cit., p. 112. 
political suspects. The 1965 amendment to the Criminal Procedure Act added a new provision dealing with bail which seriously undermined the power of the judiciary to release an accused person on bail. Until 1961, this power was essentially a judicial one, but in that year, the attorney-general was empowered to refuse bail for twelve days after arrest in all cases where he considered that public safety was threatened. In 1965, the Criminal Procedure Act was amended to permit denial of bail without a time limit until sentence or discharge. In 1967, there was the Terrorism Act whose Section 6, introduced indefinite detention in solitary confinement. In 1976, the Internal Security Amendment Act made sweeping changes to the Suppression of Communism Act of 1950, and renamed this law the Internal Security Act. Section 10 of the Internal Security Act now empowers the Minister of Justice to order the detention in prison of any person "if he is satisfied" that such person "engages in activities which endanger or are calculated to endanger the security of the State or the maintenance of public order." 49

By these laws, South Africa has made African political activity almost legally impossible. There is no longer a need for declaring a state of emergency which is disrupting, alarming and affects the confidence of overseas businessmen and investors. Now, the Government uses political "surgery," i.e., arrests and detains the leaders and potential activists, proscribes organizations or simply ban individuals likely to engage in politics which entails restrictions on their movements, usually by confining them to their homes, and limiting the nature and scope of all human contact. Such banned persons are also usually prevented from making speeches, publishing or being quoted in newspapers. They become the political "living-dead."

Such security laws not only invite abuse of detainees, but even incite such abuse. There is now overwhelming evidence that torture is extensively inflicted on political detainees and that the Government sanctions it. In fact, torture has become an administrative practice in South Africa and torture and maltreatment have bicome a routine part of the interrogation process. ${ }^{50}$

49 Ibid., pp. 112-121.

50 Political Imprisonment in South Africa, 1978, op. cit., pp. 56-7. 
This torture encompasses both physical and psychological techniques, including long periods of solitary confinement, physical assaults, denial of sleep for very long periods, round the clock interrogations, threats and intimidation and the ever prevalent electric shocks. ${ }^{51}$ The net result is the amazing numbar of political detainees who die in police custody. Between 1963 and 1972 , 22 political detainees died in "mysterious" circumstances while detained by the security police. Between August 1976 and Septembər 1977, 20 political detainees are known to have died in security police custody. This figure is probably an understatement since some people, known to have been detained, have simply disappeared. In September 1977, the whole world was shocked by the death of Black Consciousness leader Steve Biko, while in police custody - he was, however, but one in a long stream of similar deaths, nor was he the only Black Consciousness leader to meet such a cruel fate. ${ }^{52}$ This police brutality is particularly directed at political prisoners but has a much broader and general application. In May, the Minister of Police stated in Parliament that 92 people had died during 1975 while in detention.

Causes given were as follows:

\begin{tabular}{|l|r|}
\hline Natural Causes & 25 \\
Heart Failure & 1 \\
Injured during or prior to arrest & 8 \\
Suicide /self-inflicted injuries & 28 \\
Injured during attempt to escape & 9 \\
Assaulted by fellow prisoners & 9 \\
Suffocation & 1 \\
Alcoholic poisoning & 1 \\
Unknown causes (inquest not complete) & 7 \\
Abdominal haemorrhage & 1 \\
Internal Injuries & 1 \\
Motor accident & $1^{53}$ \\
\hline
\end{tabular}

The most famous non-white political prisoners are held on Robben Island, a small island located some 10 kilometers off the South African coast of Cape Town. At the end of September 1977, there were more than 450 political prisoners on Robben

51 Amnesty International, Report on Torture (New York: Farrar, Straus and Giroux, 1975), p. 131.

52 Political Imprisonment in South Africa, 1978, op. cit., pp. 63-73.

53 Survey of Race Relations 1976, p. 122. 
Island. From the numerous accounts of ex-prisoners, the aim there is not only to confine, but to break the political prisoners, both physically and spiritually. Conditions are so terrible that many who are released from there die soon after being out. ${ }^{54}$

As so far indicated, for Africans in South Africa, the most elementary human rights do not exist. The whole system is one of repression and a systematic denial of human rights. Apartheid is the very antithesis of all human decency and stands in open and contemptuous defiance of the notion that blacks are human and, therefore, entitled to human rights.

54 Political Imprisonment in South Africa, 1978, op. cit., pp. 81-6. 